\title{
The distribution and frequency of endocrine cells in the splenic lobe of grass lizard (Takydromus wolteri): An immunohistochemical study
}

\author{
S-K. Ku, H-S. Lee* \\ Pharmacology \& Toxicology Laboratory, Central Research Laboratories, Dong-Wha Pharm. Ind. Co.; \\ *Department of Herbal Biotechnology, Daegu Haany University, Gyeongsan, Korea
}

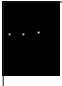

(C)2004, European Journal of Histochemistry

The regional distribution and frequency of the pancreatic endocrine cells in the splenic lobe of grass lizard, Takydromus wolteri, were studied by immunohistochemical (PAP) method using six types of specific mammalian antisera against bovine $\mathrm{Sp}-1 /$ chromogranin (bCG), serotonin, insulin, glucagon, somatostatin and human pancreatic polypeptide (hPP). The pancreas was subdivided into two regions - islet kike and exocrine regions. The frequency of each immunoreactive (IR) endocrine cells was calculated as mean number/total 100 islet cells and as mean number/total 1000 cells (including exocrine and endocrine cells) using automated image analysis process. In addition, the percentage of each IR cell was also calculated. All of six endocrine cells were demonstrated. They were dispersed in the whole pancreatic parenchyma between exocrine acinar cells, or they were also observed as islet like clusters. In islet-like regions, bCG-, insulin- and glucagon-IR cells were detected as one or two cell layer cords and they were located between this cell-cords with $14.30 \pm 5.62,61.50 \pm 9.76$ and $26.50 \pm 9.31 / 100$ cells frequencies, respectively. However, somatostatin-IR cells were mainly located in the peripheral parts not in cell-cords with $12.40 \pm 4.86 / 100$ cells, and no serotonin- and hPP-IR cells were demonstrated. In exocrine regions, all of bCG-, serotonin-, insulin-, glucagon-, somatostatin- and hPP-IR cells were detected and they occurred mainly among the exocrine parenchyma as solitary cells with $10.30 \pm 2.54,0.80 \pm 0.63,15.50 \pm 5.30$, $5.80 \pm 2.66,3.10 \pm 1.29$ and $11.00 \pm 3.33 / 1000$ cells frequencies, respectively. In addition, serotonin-IR cells were mainly located between epithelia and connective tissue of pancreatic duct. Overall, there were $0.58 \pm 0.49 \%$ serotonin-, $56.44 \pm 9.35 \%$ insulin-, $23.73 \pm 8.22 \%$ glucagon-, $11.28 \pm 3.03 \%$ somatostatin- and $7.97 \pm 2.02 \%$ hPP-IR cells

Key words: grass lizard, Takydromus wolteri, pancreas, endocrine cell, immunohistochemistry.

Correspondence: Dr. Hyeung-sik Lee, Department of Herbal Biotechnology, Daegu Haany University, Gyeongsan, 712715, Korea.

Phone: international +82.53 .8191436 .

Fax: international +82.53.8191574.

E-mail: endohist@dhu.ac.kr

Paper accepted on June 28, 2004.

European Journal of Histochemistry

2004; vol. 48 issue 4 (Oct-Dec):429-436

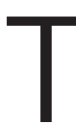
he grass lizard, Takydromus wolteri Fischer, belonging to the Laceridae in order Lacertinae is habited in east part of Russia and China with Korea and it is generally considered as being primitive palearctic lacertids, most closely related to Lacerta vivipara. They have distinct white ventrolateral band runs from tip of snot to groin. In Korea, the number and habitation of this grass lizard have been dramatically decreased because of pollution and immigration of other foreign species of amphibian and reptiles having similar feeding habits.

It is generally known that the pancreas of lacertids is could be subdivided into two parts as splenic and duodenal lobes (El-Sahly and Grimelius, 1981) and pancreas of vertebrates is subdivided into two portions, one is exocrine portions where digestive enzymes are released and the other is endocrine portions where regulatory hormones such as insulin, glucagon, somatostatin and pancreatic polypeptide (PP) are released into blood circulation. The appearance, regional distribution and relative frequency of these regulatory hormones secreted by endocrine cells in the pancreas were well recognized by Histochemistry (Kobayashi and Syed Ali, 1981), immunofluorescence method (Orci, 1982) and immunohistochemistry (Sternberger et al., 1970). Except above regulatory hormones, peptide $Y Y$-, neuropeptide $Y Y$ - (Ali-Rachedi et al., 1984), motilin- (Yamada et al., 1986), chromogranin family- (Rindi et al., 1986; Ito et al., 1987) and secretin- (Lee et al., 2003) immunoreactive (IR) cells were also demonstrated in the vertebrate pancreas. The pancreas has been treated as a valuable organ for endocrine studies, therefore endocrine pancreas has been extensively studied, associated with diabetes (Jansson and Sandler, 1988). In addition, the investigations of GEP endocrine cells have been considered as an important part of a phylogenetic studies (D'Este et al., 1994).

Until now, the regional distribution and relative 
frequency of major four types of endocrine cells, insulin, glucagon, somatostatin and PP, were reported in the lizard pancreas such as lacertid lizards (Della Rossa and Putti, 1995), desert lizard (Chalcides ocellatus and Uromasyx aegyptia) (ElSalhy and Grimelius, 1981; El-Salhy et al., 1983), green anole (Anolis carolinensis) (Rhoten and Hall, 1982) and grass lizard (Mabuya quinquetarniata) (El-Salhy and Grimelius, 1981). In addition, peptide tyrosine tyrosine- and neuropeptide tyrosine(Della Rossa and Putti, 1995) and chromogranin (CG)- (Trandaburu et al., 1999) IR cells were found in the lacertid lizard pancreas and new types of endocrine cells have been reported in the pancreas of the various vertebrates.

With the increasing demands of diabetic animal models and/or usefulness of irradiation in many fields, the regional distribution and relative frequency of pancreatic endocrine cells, especially insulin- and glucagon-producing cells in the laboratory animals have been concerned in recent years (Warbritton et al., 1994; Gomez-Dumm et al., 1995; Fu et al., 1996). Many researchers suggested that species-dependent characteristic distribution of cells producing different hormones in the pancreas of each species of animals might be due to feeding habits and now it is generally accepted (Wieczorek et al., 1998).

It was also reported that different regional distribution and relative frequency of endocrine cells in the pancreas were demonstrated in different portions even if they were (the) same pancreas of same lizard (Putti et al., 1992) and they showed speciesdependent characteristic distributional patterns in lizard species (El-Salhy and Grimelius 1981). In addition, more numerous and well-organized pancreatic endocrine systems are detected in the splenic lobes compared to that of duodenal lobes (El-Sahly and Grimelius, 1981). Despite of biological, physiological and anatomical differences between the grass lizard, Takydromus wolteri, and other lacertid species, reports have rarely dealt with the endocrine cells in the pancreas of this species. However, the distribution and relative frequency of some gastrointestinal endocrine cells in this species are reported (Lee and Ku, 2004). And, with the exception of the desert lizard (El-Salhy et al., 1983), quantitative studies of the lacertid pancreas are scarce.

The object of this study was to determine the regional distribution and quantitative frequency of the endocrine cells in the splenic lobe of pancreas of grass lizard by immunohistochemistry using antisera specific for bovie Sp-1/chromogranin (bCG), serotonin-, insulin, glucagon, somatostatin and human PP (hPP).

\section{Materials and Methods}

Ten adult ( $45 \sim 50 \mathrm{~mm}$ in length) grass lizards of the Laceridae, Takydromus wolteri Fischer, were captured around Kyungpook, Korea and both males and females were used in this study. After phlebotomy from head, the splenic lobes of pancreas were sampled according to El-Sahly and Grimelius (1981) and fixed in Bouin's solution. After paraffin embedding, 3-4 $\mu \mathrm{m}$ serial sections were prepared with routine methods. Each section was deparaffinized, rehydrated and stained with hematoxylin and eosin for light microscopic examination of the normal alimentary architecture.

The deparaffinised and rehydrated sections were treated with methanol containing $0.3 \% \mathrm{H}_{2} \mathrm{O}_{2}$ for 30 min to block any endogenous peroxidase. Subsequently, the sections were incubated for $1 \mathrm{hr}$ at room temperature, in normal goat serum ( $1: 100)$, then stained immunohistochemically to identify specific endocrine cells using peroxidase anti-peroxidase (PAP) method (Sternberger, 1979). In the first layer, the sections were incubated with antisera specific for individual pancreatic hormones for $12 \mathrm{hrs}$ at $4^{\circ} \mathrm{C}$. Details of specific antisera used as the first layer are listed in Table 1. After rinsed in phosphate buffered saline (PBS; $0.01 \mathrm{M}, \mathrm{pH} 7.4$ containing $0.05 \%$ tween), Anti-rabbit or -guinea pig IgG serum raised in goat (Sigma, St. Louis M0, USA) was used as the second layer at 1:200 for $1 \mathrm{hr}$ at room temperature. They were then washed with PBS buffer and the PAP complex (Sigma, St. Louis MO, USA) was used as the third layer at $1: 400$ for $1 \mathrm{hr}$ at room temperature. The peroxidase reaction was carried out in a solution 3,3'-diaminobenzidine tetrahydrochloride containing $0.01 \% \mathrm{H}_{2} \mathrm{O}_{2}$ in Tris- $\mathrm{HCl}$ buffer $(0.05 \mathrm{M}, \mathrm{pH}$ 7.6). After immunostained, the sections were lightly counterstained with Mayer's hematoxylin and the IR cells were observed under light microscope.

The specificity of each immunohistochemical reaction was determined as recommended by Sternberger (1979), including the replacement of specific antiserum by the same antiserum, which had been preincubated with its corresponding anti- 
Table 1. Antisera used in this study

\begin{tabular}{llll}
\hline \hline Antisera raised* & Code & Source & Diluton \\
\hline bCG & 805398 & Dia Sorin, Stillwater, USA & $1: 1000$ \\
Serotonin & B068082C & BioGenex Lab., San Ramon, USA & $1: 20$ \\
Insulin & 842613 & Diasorin, Stillwater, USA & $1: 2000$ \\
Glucagon & $8240-0004$ & Biogenesis, Kingston, USA & $1: 800$ \\
Somatostatin & PU0421295 & BioGenex Lab., San Ramon, USA & $1: 20$ \\
hPP1 & A619 & DAKO corp., Carpenteria, USA & $1: 600$ \\
& & & \\
\hline
\end{tabular}

*All antisera were raised in rabbits except for insulin, which were raised in a guinea pig. ${ }^{11}$ bCG: bovine Sp-1/chromogranin; hPP: humane pancreatic polypeptide.

gen. The frequencies of IR cells were calculated as mean \pm standard deviation (S.D.) of 10 parts $(n=10)$ of pancreatic parenchyma. In islet-like regions, among 100 endocrine cells, cells showing immunoreactivities against each antiserum were counted using automated image analysis process (Soft Image System, Germany) attached to light microscopy, and, in exocrine regions, among 1000 parenchymal cells, cells showing immunoreactivities against each antiserum were counted. In addition, the percentage of IR cells to each antiserum was also determined using counted IR cell numbers.

\section{Results}

In this study, six types of IR endocrine cells were detected with the antisera to bCG, serotonin, insulin, glucagon, somatostatin and hPP in the splenic lobes of pancreas of grass lizard. The pancreas was divided into exocrine and islets-like regions. Most of islet-like regions showed cord shaped consisted of one or two layers of cell-cords. According to the types of IR cells, different regional distribution and quantitative frequency were

Table 2. Quantitative frequencies of the endocrine cells in the pancreas of grass lizard, Takydromus wolteri

\begin{tabular}{lccc}
\hline \hline IR cells & $\begin{array}{c}\text { Number of IR cells } \\
\text { in islet-like regions* }\end{array}$ & $\begin{array}{c}\text { Number of IR cells in } \\
\text { exocrine regions** }\end{array}$ & $\begin{array}{c}\text { Percentage } \\
\text { of each IR cells (\%) }\end{array}$ \\
\hline bCG 1) & $14.30 \pm 5.62$ & $10.30 \pm 2.54$ & Not calculated \\
Serotonin & $0.00 \pm 0.00$ & $0.80 \pm 0.63$ & $0.58 \pm 0.49$ \\
Insulin & $61.50 \pm 9.76$ & $15.50 \pm 5.30$ & $56.44 \pm 9.35$ \\
Glucagon & $26.50 \pm 9.31$ & $5.80 \pm 2.66$ & $23.73 \pm 8.22$ \\
Somatostatin & $12.40 \pm 4.86$ & $3.10 \pm 1.29$ & $11.28 \pm 3.03$ \\
hPP 2) & $0.00 \pm 0.00$ & $11.00 \pm 3.33$ & $7.97 \pm 2.02$ \\
\hline
\end{tabular}

Quantitative frequencies were calculated using automated image analysis process (Soft Image System, Germany) attached to light microscopy; *Cell numbers 100 islet cells; **Cell numbers/1000 parenchymal cells; 1) bCG: bovine Sp-1/chromogranin; 2) hPP: human pancreatic polypeptide.

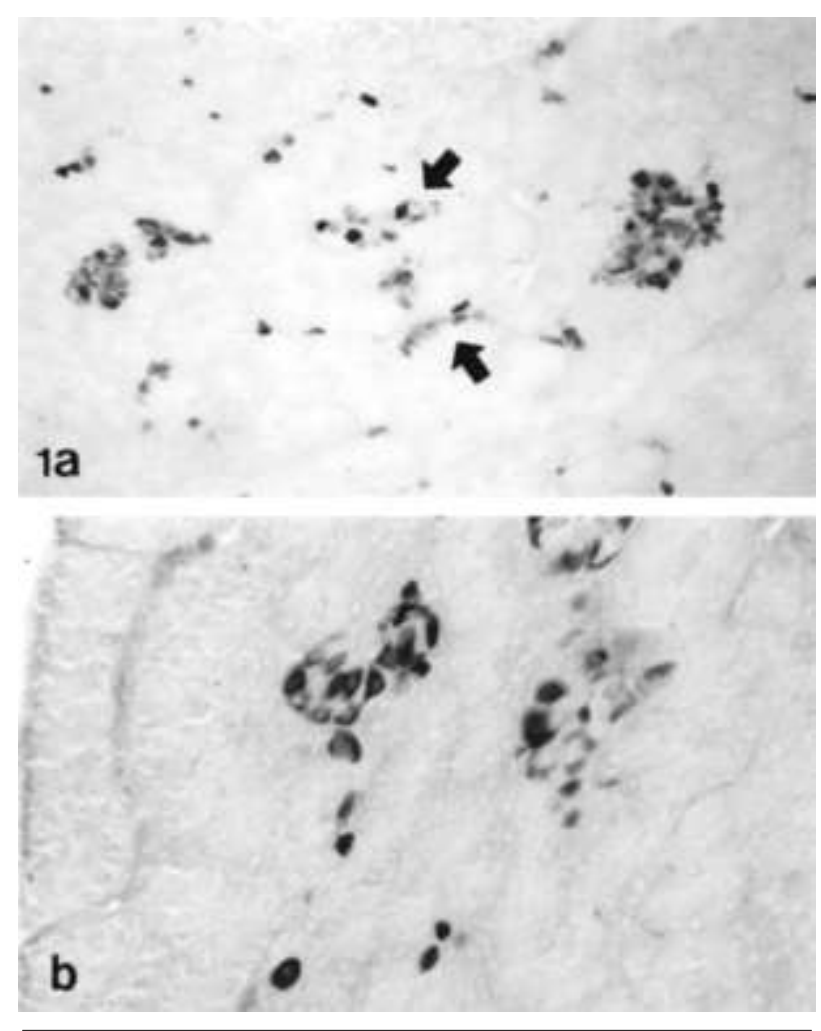

Figure 1. bCG-IR cells were distributed as solitary cells in the exocrine regions (a) and/or as clusters in the islet-like regions (b). In addition, they were also dispersed in some islet-like regions (a, arrows) of grass lizard. a. ×150; b. ×300; PAP method.

observed and these differences are shown in Table 2. Spherical to spindle or occasionally oval to round-shaped immunoreactive cells were located in the pancreas. They were dispersed in the whole pancreatic parenchyma between exocrine acinar cells, or they were also observed in islet-like regions.

\section{bCG-IR cells}

These cells were located in islet-like and exocrine regions. In case of exocrine, they were dispersed throughout the whole pancreas parenchyma, between exocrine acinar cells as solitary cells (Figure 1a). In case of islet-like regions, relatively small numbers cells were dispersed in the islets mainly in the central regions (Figure $1 a, b$ ) or they were situated in the cell-cords that consisted of one or two cell layers (Figure 1a, arrows). bCG-IR cells showed $14.30 \pm 5.62 / 100$ cells frequencies in isletlike regions and $10.30 \pm 2.54 / 1000$ parenchymal cells frequency in exocrine.

\section{Serotonin-IR cells}

These cells were restricted to exocrine pancreas especially to the region of the pancreatic duct 


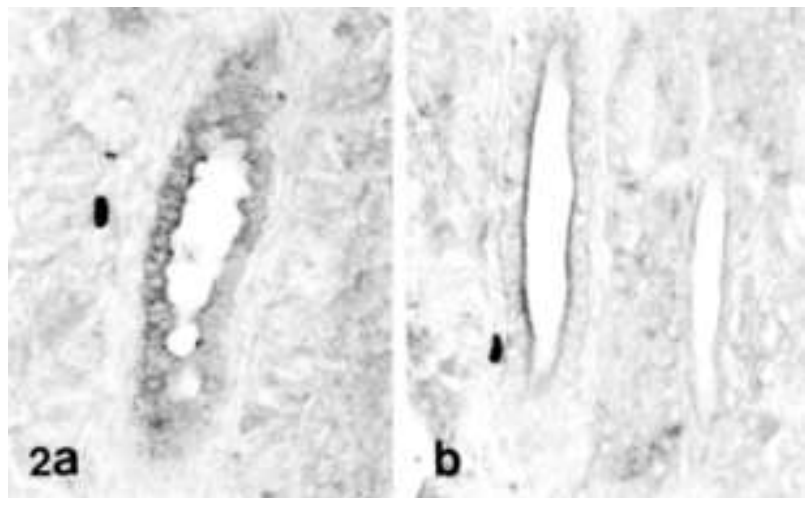

Figure 2. Serotonin-IR cells were distributed as solitary cells in the pancreatic duct between connective tissue and epithelia lining of grass lizard (a, b). a, b. $\times 300$; PAP method.

between connective tissue and epithelia (Figures $2 a, b)$. Serotonin-IR cells showed a frequency of $0.80 \pm 0.63 / 1000$ parenchymal cells frequency in exocrine and they occupied approximately $0.58 \pm$ $0.49 \%$ of total IR cell population (Table 2 ). This is the least abundant cell type in the pancreas of this grass lizard.

\section{Insulin-IR cells}

These IR cells were located in islet-like and exocrine regions. In exocrine regions, they were dispersed throughout the whole pancreas parenchyma, between exocrine acinar cells as solitary or two to three cell clusters (Figures $3 \mathrm{a}-\mathrm{c}$ ). In case of isletlike regions, insulin-IR cells were situated in the cell-cords that consisted of one or two cell layers

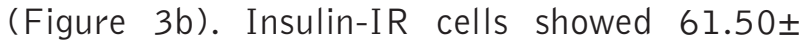
9.76/100 cells frequencies in islet-like regions and $15.50 \pm 5.30 / 1000$ parenchymal cells frequency in exocrine regions. Insulin-IR cells occupied approximately $56.44 \pm 9.35 \%$ of total IR cell population (Table 2). This is the most predominant cell type in the pancreas of this grass lizard.

\section{Glucagon-IR cells}

These cells were located in islet-like and exocrine regions similar to other types of IR cells. In case of exocrine regions, they were dispersed in pancreas parenchyma, between exocrine acinar cells as solitary or two to three cell clusters (Figure 4a). In case of islet-like regions, glucagon-IR cells were situated in the cell-cords that consisted of one or two cell layers (Figures 4b, c) similar to that of insulinIR cells. Glucagon-IR cells showed $26.50 \pm$ $9.31 / 100$ cells frequencies and 5.80 $2.66 / 1000$

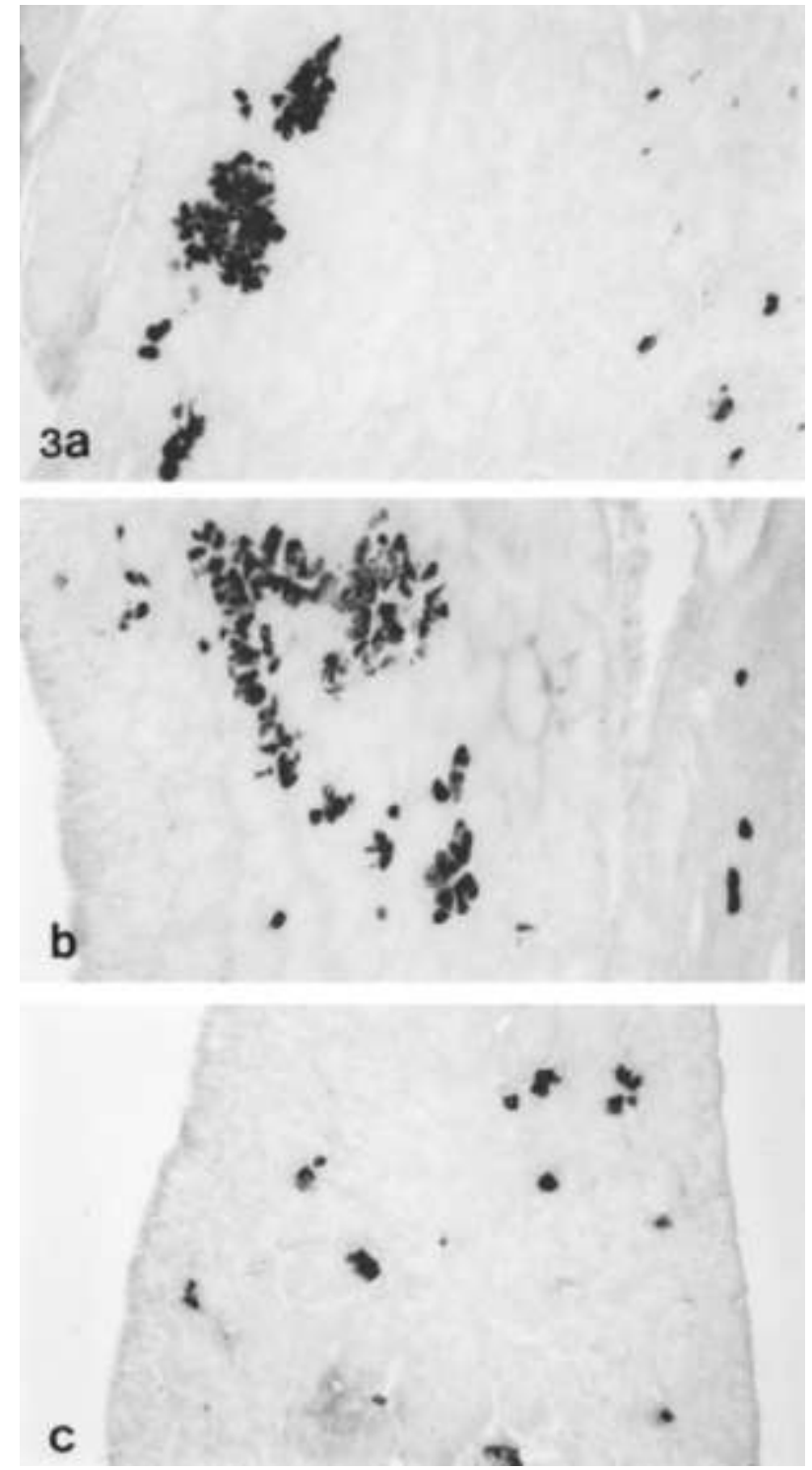

Figures 3. Insulin-IR cells were distributed as cell cords in the islet-like regions $(a, b)$ and some cells were also dispersed in the exocrine regions as solitary and/or two to three cell clusters (a-c). a - c. $\times 150$; PAP method.

parenchymal cells frequency in islet-like and exocrine regions, respectively. They occupied approximately $23.73 \pm 8.22 \%$ of total IR cell population (Table 2). This is the second predominant cell type in the pancreas of this grass lizard.

\section{Somatostatin-IR cells}

These IR cells were also located in islet-like and exocrine regions. Somatostatin-IR cells were dispersed in restricted pancreas parenchyma of exocrine regions between exocrine acinar cells as solitary or two cell clusters (Figure $5 b$ ). In case of 

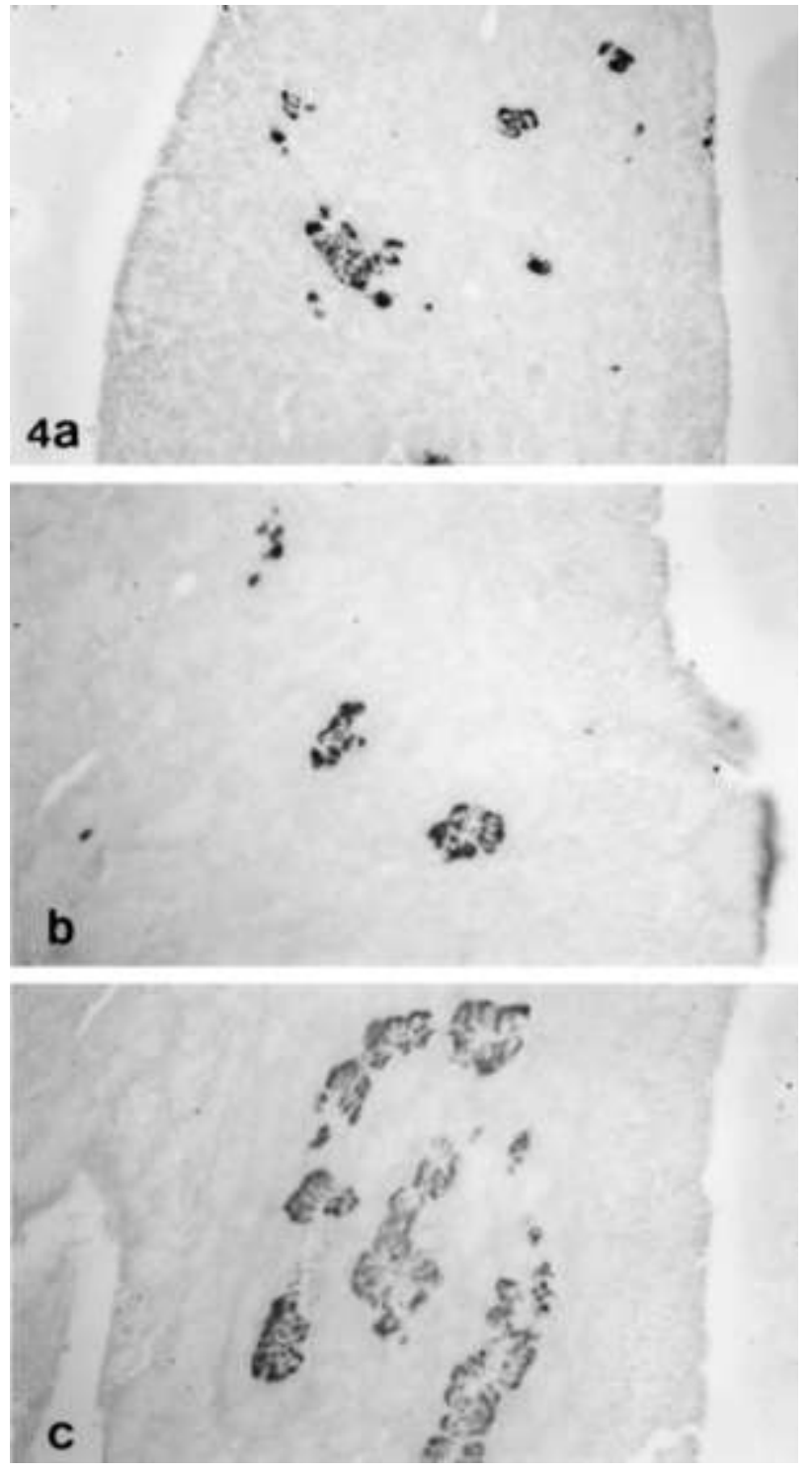

Figure 4. Glucagon-IR cells were distributed as single, two to two cell clusters in the exocrine regions of grass lizard (a). In addition, they were distributed as cell cords in the islet-like regions $(b, c)$ of grass lizard. a - c. ×150; PAP method.

islet-like regions, most of somatostatin-IR cells were situated in the peripheral parts of cell-cords and relatively low frequencied cells were also observed in the cell-cords that consisted of one or two cell layers (Figure 5a). Somatostatin-IR cells showed $12.40 \pm 4.86 / 100$ cells frequencies in isletlike regions and $3.10 \pm 1.29 / 1000$ parenchymal cells frequency in exocrine. They occupied approximately $11.28 \pm 3.03 \%$ of total IR cell population (Table 2). This is the third most abundant cell type in the pancreas of this grass lizard.
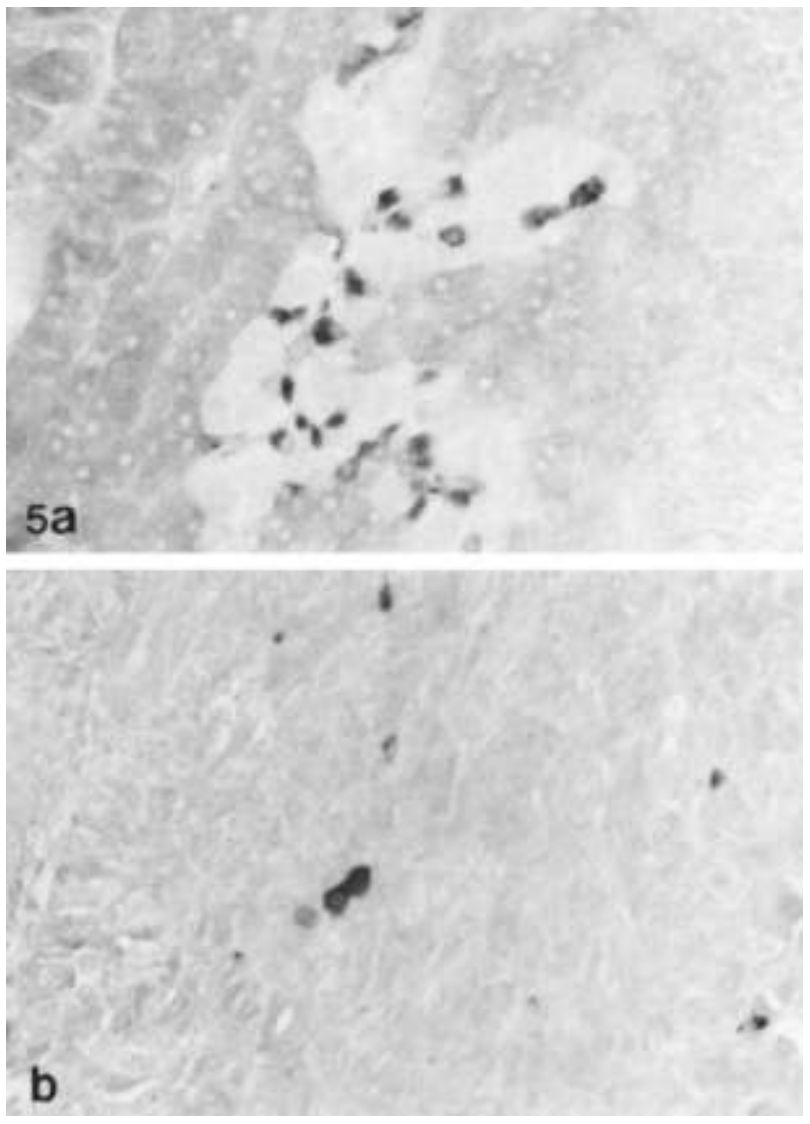

Figure 5. Somatostatin-IR cells were distributed in the outside, peripheral parts of cell cords in islet-like regions (a) and as solitary or two cell clusters in the exocrine regions (b) of grass lizard. a, b. $\times 300$; PAP method.

\section{hPP-IR cells}

hPP-IR cells were restricted to the exocrine regions. They were dispersed throughout the whole exocrine pancreas parenchyma, between exocrine acinar cells as solitary cells (Figures $6 a, b$ ). hPP-IR cells showed $11.00 \pm 3.33 / 1000$ parenchymal cells frequency in exocrine regions and they occupied approximately $7.97 \pm 2.02 \%$ of total IR cell popuIation (Table 2). This is the fourth most abundant cell type in the pancreas of this grass lizard.

\section{Discussion}

In the splenic lobe of pancreas of the grass lizard, Takydromus wolteri, all of six endocrine cells were dispersed in the whole pancreatic parenchyma, between exocrine acinar cells or they were also observed in islet-like regions. The cord or duct-like pancreatic islets were specific observation in some 

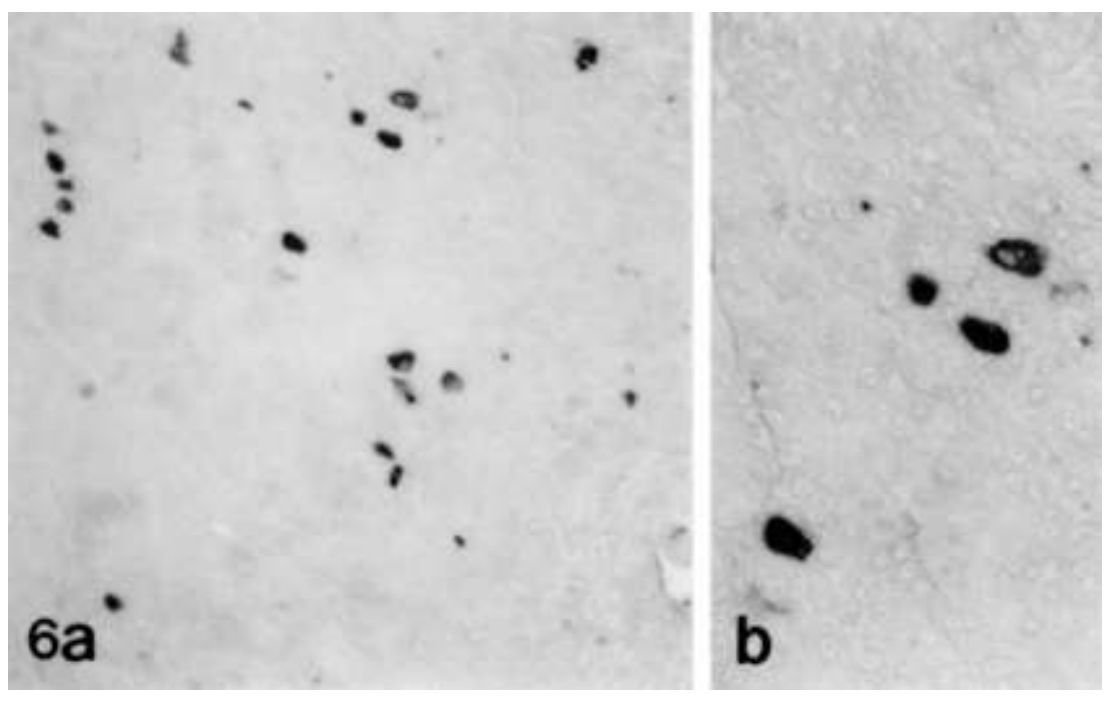

Figure 6. hPP-IR cells were distributed as single cells $(a, b)$ in the exocrine pancreas of grass lizard. a. $\times 150$; b. $\times 300$; PAP method.

species of snake (Lee and Lee, 1992) but they were not generally demonstrated in the pancreas of lacertid lizards. However, in this study similar to that of some species of snake, most of islet-like regions showed cord shape and it is considered to be a species-dependent characteristic appearance.

bCG belongs to a family of large anionic proteins (CG A, B and secretogranin II), the members of which are known to be present in the secretory granules of a broad spectrum of amine and peptideproducing cells of adrenal medulla and gastroenteropancreatic (GEP) endocrine system, as well as in some neurons of the peptidergic and catecholaminergic nervous system of several mammals (Rindi et al., 1986; Reinecke et al., 1991). CGs have been found to occur in large variety of endocrine organs and cells outside the adrenal medulla, and they have been claimed as common "markers" of all neuroendocrine cells (Cohn et al., 1984). In addition, Trandaburu et al. (1999) reported that CG A-IR cells were found only in the turtle pancreas among the four reptile species belonging to the turtles, lizards and snakes whereas secretogranin II-IR cells appeared both in the turtle and snake. In addition, no CG A-IR cells were demonstrated in the pancreas of red-eared slider (Ku et al., 2000). In the present study, somewhat differed from previous studies (Trandaburu et al., 1999; Ku et al., 2000), bCG-IR cells were detected in the pancreatic islets and exocrine of this grass lizard. However, it is considered that single use of bCG is not suitable as a marker of endocrine cells in the pancreas of this grass lizard because a density of bCG-IR cells was lower than that of insulin- and glucagon-IR cells. Until now, observations of reptilian species were restricted, and the possibility of the usefulness of the CGs as a common marker for neuroendocrine cells in the pancreas of other reptilian species should be investigated.

Serotonin consisted of monoamines and was widely distributed in nervous system and GEP endocrine cells (EI-Salhy et al., 1985). Appearance of serotonin-IR cells showed species-dependent differences in the pancreas of the vertebrates (Ding et al., 1991). In the reptilian pancreas including lacertid lizards, they were demonstrated in the exocrine regions especially to the peripheral region of duct epithelia lining with very lowered frequency (Perez-Tomas et al., 1989; Ding et al., 1991; Ku et al., 2000). Similar to these previous studies (PerezTomas et al., 1989; Ding et al., 1991; Ku et al., 2000), serotonin-IR cells were restricted to the pancreatic duct of this grass lizard and they showed the least abundant frequency.

Insulin is synthesized in the B cells of the pancreatic islets and regulates the serum glucose levels (Hsu and Crump, 1989). In the pancreas of the reptilian species, insulin-IR cells were present as solitary cells or grouped in the pancreatic islets and they were located in the central core of the pancreatic islets (Perez-Tomas et al., 1989; Morescalchi et al., 1997). And these IR cells were located in the islet center and comprised 3\% of dorsal and $0.2 \%$ of ventral lobe volume in the squamate reptile, the desert lizard (El-Sahly et al., 1983). In addition, Putti et al. (1992) reported that insulin-IR B cells appeared in 11 species, 3 genera of lacertids and different distributional patterns were seen in the 
pancreatic islets but these IR cells were mainly distributed in the central core of the pancreatic islets. From these previous reports (El-Sahly et al., 1983; Perez-Tomas et al., 1989; Putti et al., 1992; Morescalchi et al., 1997), insulin-IR cells that were the most predominant cell types in pancreas were located in the central core of the pancreatic islets, some cells were scattered in the inter acinar regions of the exocrine pancreas. Similar to those of other reptilian species, insulin-IR cells were the most predominant cell types and they were observed in the exocrine pancreas in this grass lizard. But the appearance in islet-like regions and distributional patterns in this islet-like region considered as species-dependent distributional patterns.

Glucagon is synthesized in the A cells of the pancreas and regulates glucose levels in blood ( $\mathrm{Hsu}$ and Crump, 1989). Glucagon-IR cells were distributed in the peripheral mantle zone of the pancreas of 11 species of lacertids (Putti et al., 1992) and some of these IR cells were located in the central portions of the pancreatic islets. In the turtles, no glucagon-IR cells were detected in the central portion of the pancreatic islets (Perez-Tomas et al., 1989; Ku et al., 2000). In addition, these IR cells were distributed in the peripheral regions of the pancreatic islets, exocrine pancreas and pancreatic duct of the Testudo graeca (Garcia-Ayala et al., 1987). Similar to those of other reptilian species, glucagon-IR cells were the second most predominant cell types and most of these IR cells were observed in the exocrine pancreas but the appearance in the islet-like regions and distributional patterns were considered as species-dependent distribution patterns.

Somatostatin, which consisted of 14 amino acids, was isolated from hypothalamus of sheep for the first time. It could be divided into straight form and cyclic form (Brazeau et al., 1973). In the present study, most of somatostatin-IR cells were dispersed in the exocrine pancreas and located in the outside regions cell-cords in the islet-like regions. Different from the present study, somatostatin-IR cells in the pancreatic islets of the reptilian species were located in the peripheral region of the 11 species of lacertids (Putti et al., 1992), desert lizard (El-Sahly et al., 1983) and anolian lizard (Rhoten and Smith, 1978). And also they were dispersed in the exocrine pancreas (Rhoten and Smith, 1978; El-Sahly et al., 1983; Putti et al., 1992). Somatostatin-IR cells showed the fourth highest frequency in the present study. These results were quite similar to those of desert lizard (El-Sahly et al., 1983). However, the distributional patterns in the islet-like regions were considered as a species-dependent characteristic of this grass lizard.

PP is a peptide hormone containing 36 amino acids, which is synthesized by $F$ cells in the pancreatic islets (Hsu and Crump, 1989). Since PP-IR cells have been described for the first time in the lizard pancreas (Rhoten and Smith, 1978), the occurrence of these cells have been demonstrated in the pancreas of the reptiles (Rhoten and Smith, 1978; ElSahly et al., 1983; Agulleiro et al., 1985; GarcaAyala et al., 1987; Putti et al., 1992; Ku et al., 2000). From these previous results, PP-IR cells were dispersed in the exocrine pancreas in a case of the reptilian species but they showed different distribution according to sampling portions (El-Sahly et al., 1983). Similar to those of the previous reports, hPPIR cells were restricted to the exocrine pancreas of this grass lizard. They showed the fourth highest frequency and these results were corresponded to those of desert lizard (El-Sahly et al., 1983).

In conclusion, distributional patterns of IR cells in the splenic lobe of pancreas of this species of grass lizard were quite similar to those of other reptilian species but the cord-shaped islet-like regions showing different morphology and distributional patterns of endocrine cells of this grass lizard was considered as species-dependent characteristics.

\section{References}

Agulleiro B, Garcia Ayala A, Abad ME. An immunocytochemical and ultrastructural study of the endocrine pancreas of Pseudemys scripta elegans (Chelonia). Gen Comp Endocrinol 1985;60:95-103.

Alli-Rachedi A, Varndell IM, Adrian TE, Gapp DA, Van Noorden S, Bloom SR, et al. Peptide YY (PYY) immunoreactivity is co-stored with glucagon-related immunoreactants in endocrine cells of the gut and pancreas. Histochemistry 1984;80:487-91.

Brazeau P, Vale W, Burgurs R, Ling N, Butcher M, Rivier J, Guillermin R. Hypothalamic polypeptide that inhibits the secretion of immunoreactive pituitary growth hormone. Science 1973;179:77-9.

Cohn DV, Elting JJ, Frick M, Elde R. Selective localization of the parathyroid secretory protein $\beta$ /adrenal medulla chromogranin $A$ protein family in a wide variety of endocrine cells of the rat. Endocrinology 1984;144:1963-74.

Della Rossa A, Putti R. The endocrine pancreas of lacertids: an immunocytochemical study of the genera Pedioplanis and Meroles. Eur J Histochem 1995;39:47-58.

D’Este L, Buffa R, Pelagi M, Siccardi AG, Renda T. Immunohistochemical localization of chromogranin $A$ and $B$ in the endocrine cells of the alimentary tract of the green frog, Rana esculenta. Cell Tissue Res 1994;277:341-9.

Ding WG, Fujimura M, Tooyama I, Kimura H. Phylogenetic study of serotonin-immunoreactive structures in the pancreas of various vertebrates. Cell Tissue Res 1991;263:237-43.

El-Salhy M, Abu-Sinna G, Wilander E. The endocrine pancreas of a squamate reptile, the desert lizard (Chalcides ocellatus). A histolog- 
ical and immunohistochemical investigation. Histochemistry 1983; 78:391-7.

El-Salhy M, Grimelius L. Histological and immunohistochemical studies of the endocrine pancreas of lizards. Histochemistry 1981; 72:237-47.

El-Salhy M, Winder $\mathrm{E}$, Lundqvist M. Comparative studies of serotoninlike immunoreactive cells in the digestive tract of vertebrates. Biomedical Res 1985;6:371-5.

Fu Q, Honda M, Ohgawara H, Igarashi N, Toyada C, Omori $Y$, et al. Morphological analysis of pancreatic endocrine cells in newborn animals delivered by experimental diabetic rats. Diabetes Res Clin Pract 1996;31:57-62.

Garcia-Ayala A, Lozano MT, Agulleiro B. Endocrine pancreas of Testudo graeca L. (Chelonia) in summer and winter: an immunocytochemical and ultrastructural study. Gen Com Endocrinol 1987;68:235-48.

Gomez-Dumm CL, Console GM, Lunna GC, Dardenne M, Goya RG. Quantitative immunohistochemical changes in the endocrine pancreas of nonobese diabetic (NOD) mice. Pancreas 1995;11:396-401.

Hsu WH, Crump MH. The endocrine pancreas. In Veterinary endocrinology and reproduction. McDonald LE and Pineda $\mathrm{MH}$, editors). Lea \& Febiger, Philadelphia 1989;186-201.

Ito $H$, Hashimoto $Y$, Kitagawa $H$, Kon $Y$, and Kudo N. Distribution of chromogranin containing cells in the porcine gastroenteropancreatic endocrine system Jpn J Vet Sci 1987;50:395-404.

Jansson L, Sandler S. The influence of cyclosporin A on the vascular permeability of the pancreatic islets and on diabetes induced by multiple low dose of streptozotocin in the mouse. Virchows Archiv. A Pathol. Anat Histopathol 1988;412:225-30

Kobayashi K, Syed-Ali S. Cell types of the endocrine pancreas in the shark, Scylliorhinus stellaris as revealed by correlative light and electron microscopy. Cell Tissue Res 1981;215:475-90.

Ku SK, Lee HS, Lee JH, Park KD. Immunohistochemistry of the pancreatic endocrine cells of the red-eared slider (Trachemys scripta elegans). Korean J Biol Sci 2000;4:187-93.

Lee JH, Ku SK, Lee HS, Kitagawa H. An immunohistochemical study of endocrine cells in the pancreas of the Red-bellied frog (Bombina orientalis). Eur J Histochem 2003;47:165-72.

Lee $\mathrm{JH}$, Lee HS. Immunohistochemical studies of the pancreatic endocrine cells of the various animals. Korean J Vet Res 1992;32: 497-510.

Lee HS, Ku SK. An immunohistochemical study of endocrine cells in the alimentary tract of the grass lizard, Takydromus wolteri Fischer (Laceridae). Acta Histochem 2004;106:171-78.

Morescalchi AM, Gaccioli M, Faraldi G, Tagliafierro G. The gastroenteric-pancreatic neuroendocrine system in two reptilian species,
Chalcides chalcides and Zoonosaurus madascariensis (Sauridae). Eur J Histochem 1997;41:29-40.

Orci L. Macro-and micro-domains in the endocrine pancreas. Diabetes 1982;31:538-64.

Perez-Tomas R, Ballesta J, Pastor LM, Madrid JF, Polak JM. Comparative immunohistochemical study of the gastroenteropancreatic endocrine system of three reptiles. Gen Comp Endocrinol 1989;76;171-91.

Putti R, Della Rosa A, Varano L, Laforgia V, Cavagnuolo A. An immunocytochemical study of the endocrine pancreas in three genera of lacertids. Gen Comp Endocrinol 1992;87:249-59.

Rindi G, Buffa R, Sessa F, Tortora O, Solcia E. Chromogranin A, B and $C$ immunoreactivities of mammalian emdocrine cells: Distribution from costored hormones/prohormones and relationship with argyrophil component of secretory granules. Histochemistry 1986;85: 19-28.

Reinecke M, Hoog A, Ostenson CG, Efendic S, Grimelius L, Falkmer S. Phylogenetic aspects of pancreastatin-and chromogranin-like immunoreactive cells in the gastro-entero-pancreatic neuroendocrine system of vertebrates. Gen Comp Endocrinol 1991;83.167-82.

Rhoten WB, Hall CE. An immunocytochemical study of the cytogenesis of pancreatic endocrine cells in the lizard, Anolis carolinensis. Am J Anat 1982;163:181-93, .

Rhoten WB, Smith $\mathrm{PH}$. Localization of four polypeptide hormones in the saurian pancreas. Am J Anat 1978;151:595-601.

Sternberger $L A$. The unlabeled antibody peroxidase-antiperoxidase (PAP) method. In Immunocytochemistry. (Ed. Sternberger, LA), John Wiley \& Sons, New York 1979;104-69.

Sternberger LA, Hardy PH, Cuculis JJ, Meyer HG. The unlabeled antibody enzyme method of immunocytochemistry: Preparation and properties of soluble antigen-antibody complex (Horseradish peroxidase-antihorseradish peroxidase) and use in identification of spirochetes. J Histochem Cytochem 1970;18:315-33.

Trandaburu T, Syed-Ali S, Trandaburu I. Granin proteins (chromogranin $A$ and secretogranin IIC23 and (26-3) in the endocrine pancreas of reptiles Anat Anz 1999;181;489-94.

Warbritton A, Gill AM, Yen TT, Bucci T, Wolff GL. Pancreatic islet cells in preobese yellow Avy/- mice: relation to adult hyperinsulinemia and obesity. Proc Soc Exp Biol Med 1994;206:145-51.

Wieczorek G, Pospischil A, Perentes EA. Comparative immunohistochemical study of pancreatic islets in laboratory animals (rats, dogs, minipigs, nonhuman primates). Exp Toxicol Pathol 1998;50:151-72.

Yamada J, Campos VJM, Kitamura N, Pacheco AC, Yamashita T, Yanaihara N. An immunohistochemical study of endocrine cells in the pancreas of Caiman latirostris (Alligatorinae), with special reference to pancreatic motilin cells. Biomed Res 1986;7:199-208. 